tice. Unfortunately, powerful remedies are often used very indiscriminately; mercurials are prescribed when they can do no good, and diuretics are expected to promote the absorption of serum when they themselves are not absorbed. Purgatives are agents sometimes very beneficial, or again most disastrous in their effects. In the ascites connected with general atrophic changes, our hope of relief is by sustaining the system ; in the obstructive ascites connected with pulmonary and cardiac disease, free action on the abdominal glands and on the bowels by mercurial or other purgative and diuretic medicines afford great relief; but in hepatic obstruction and ascites, the diuretics are most unsatisfactory, for they are not absorbed. Again in glandular ascites, hydragogue cathartics are often followed by speedy diminution of the ascites. In strumous disease and in cancerous tubera on the peritoneum, all these depressing measures are alike injurious, and their use may be followed by increased effusion and exhaustion, or they may cause acute in flammatory disease. Powerful purgatives, sometimes beneficial in these cases, are always attended with risk. Even in instances of ascites connected apparently with an abnormal condition of the liver, rapid absorption will take place without any mercurial medicines, although these are very frequently prescribed. The following cases may be taken as examples :Charles L_-, aged thirty-six, was admitted under my care into Guy's Hospital on March 20th. He was a whitesmith, and, although he had had occasional indigestion, he had enjoyed good health till the present attack. He was of temperate habits, but twelve years ago he had syphilis. For about a fortnight he had experienced tightness of the abdomen, with swelling, and this had increased so much as to confine him at home for six days. He had some pain across the back, and shortness of breath. He was a strong man. The thoracic viscera were healthy; the abdomen was large; fluctuation very distinct; the liver could not be felt. The urine contained lithates, but no albumen. There was no febrile excitement, the temperature being only $98^{\circ}$. Nitro-hydrochloric acid, with sulphate of magnesia and with infusion of orange-peel, were given; and on the 23rd, the bowels being confined, the compound jalap powder was prescribed. On April 4th there was less effusion; the abdomen was smaller and more resonant; there was no pain. The ascites gradually lessened, and on the 25th the patient was convalescent.

Another instance of hepatic ascites occurred in a man, aged thirty-nine, of intemperate habits, admitted under my care with hæmatemesis and melæna. He was much blanched. He was a large man. The abdomen was full and large, and there was some tenderness at the scrobiculus cordis. The peritoneum contained fluid in small quantity. When the hæmorrhage had ceased, severe pain came on at the scrobiculus cordis, greatly increased by food. The irritability of stomach subsided under the use of bismuth and morphia; and on April lst the fluid in the abdomen had greatly increased, so that there was marked ascites. Iodide of potassium was given three times a day, and the compound steel pill once a day. Under this treatment he rapidly improved; and although (April 25th) some fluid still existed in the abdomen, he was able to walk about, to take solid food, and was convalescent.

In both these instances, although the ascites was from hepatic disease, the use of mercurial medicine was not required, and the absorption of fluid took place rapidly under the use of tonics and simple purgatives.

The ascites from the splenic enlargenent of miasmatic poisoning sometimes disappears in a short time under the use of quinine, as in the following case :-

A sailor, aged twenty-one, was placed under my care in Guy's Hospital on the 13th of September, 1865. He had been in the West Indies and America. During the month of May, at New York, he had ague, and his health failed. Three months later ascites came on, with pain in the back, and he was tapped twice. On admission he was spare, the chest was free from morbid symptom, but the heart was feeble; the bowels were normal. The abdomen was much enlarged, the superficial veins were distinct, and the umbilicus had hernial protrusion containing serous fluid; fluctuation was very distinct. The spleen was very much enlarged. The blood did not contain any excess of white corpuscles, nor did the urine contain any albumen. Over the splenic enlargement a friction sound was distinctly audible. On September 26 th quinine was given in two-grain doses three times a day. The ascites lessened, the veins lost their distinctness, and the spleen became smaller. At the end of October the ascites was nearly gone, and several weeks later he left the hospital. After some months the ascites returned, and under the care of one of my colleagues quinine was again given with the same beneficial result.
In few diseases is the fact more obvious than in ascites that each case must be regarded in its own particular bearings, and it is as impossible as it is unwise to lay down positive rules of treatment. In many of the forms of ascites that we have mentioned paracentesis abdominis would be utterly out of the question, whilst in others it tends not only to relieve most distressing distension, but to prolong life for many months, or even years. But there are three states in which the operation is attended with unusual danger and liability to great prostration or acute peritonitis: 1, excessive feebleness of the heart's action; 2 , persistent congestion of the peritoneal vessels; and 3 , local organic change in the serous membrane. It is the settled opinion of many practitioners that mercurial medicines always promote absorption, and that diuretics and purgatives have a like effect; whereas it will often be found that the most effectual way of promoting the absorption of diseased products is to re-establish, if possible, healthy nutritive action.

\section{ON A CASE OF TALIPES EQUINO-VARUS,}

\section{BY FREDERIC CLOWES, M.R.C.S.}

AT the suggestion of an eminent London surgeon, I forward the following case for publication in THE LANCET. It illustrates the fact that in somewhat severe cases tenotomy may sometimes be avoided, if only a proper plan and apparatus be used; also that free tenotomy, without careful after-treatment and effective instruments, is useless.

G. F-_, aged two years and a half. Congenital equino-varus of left foot. The member was considerably inverted, so that the child walked on the outer side of the dorsum, which was shown by a well-marked callosity in that position. The heel was much raised, and the foot could not be brought to a right angle with the leg, nor everted. There was considerable rigidity of all the parts concerned in the deformity.

On June 22nd, 1866, I applied a padded straight splint to the outer side of the foot and leg. On the 30 th the foot was brought so far into line with the leg and improved in shape as to allow of the use of an instrument with advantage. * Dr. Little's double-hinged lever apparatus was now applied, and complete restoration of form and eversion were obtained on July 22 nd. At this time the case was seen by a surgeon of considerable experience, who advised section of the tendo Achillis; but as there seemed to be some signs of its yielding, I determined to try to bring down the heel without dividing it. Flexion of the foot was now therefore begun by means of the thumbscrew, and progressed so well that on August 18th this part of the treatment was completed, the foot being now easily and painlessly bent to the full natural angle. The engravings show the appearance of the limb before and after treatment.

I have reported ther cases cured by the aid of the instru. ment above named; but in all of them the tendo Achillis and sometimes other tendons were divided. Since that time I have had cases of talipes varus in which this apparatus has aided me in the treatment both with and without tenotomy ; but the one now described was the most rigid, and appeared least likely to be cured without division of the tendons. The case is also thoroughly satisfactory, a well-formed and strong foot being obtained, with as little tendency to relapse as would have been shown if the tendons had been divided, or rather redivided; for they had once been operated on, as will be seen below, and although eighteen months previous to the present treatment, yet it is probable that the parts yielded more readily than they would have done if no tendons had ever been cut, and probably, as redivision proved to be unnecessary, it might have been injurious. In some cases much harm is doubtless done by endeavouring to flex the foot without dividing the tendo Achillis, the foot really yielding at the tarsus instead of at the ankle-joint, and a weak and ralgoid foot is the result. In the treatment of the eversion, a like error may be committed-that is to say, obtaining this without really replacing the tarsal bones; but neither of these evils occurred here.

This patient belonged to the numerous class of "imperfectl cured and relapsed cases." About eighteen months before I saw it, the tendons of the tibialis anticus and posticus muscles and the tendo Achillis were divided by an eminent provincial surgeon. The foot was partially brought into position, and

$$
\begin{aligned}
& \text { * Made by Ernst, 80, Charlotte-street, Fitzroy-square. } \\
& + \text { Med. Times and Gaz., Anvil } 7 \text { th, ? } 5 \text { C. }
\end{aligned}
$$


after three weeks' treatment the child was sent home, the only retentive means being a leather-boot, with two indiarubber springs passing from it to a calf-band. The improvement obtained gradually diminished, and by the time I saw him the deformity had retnmed to its originul state. Nuch
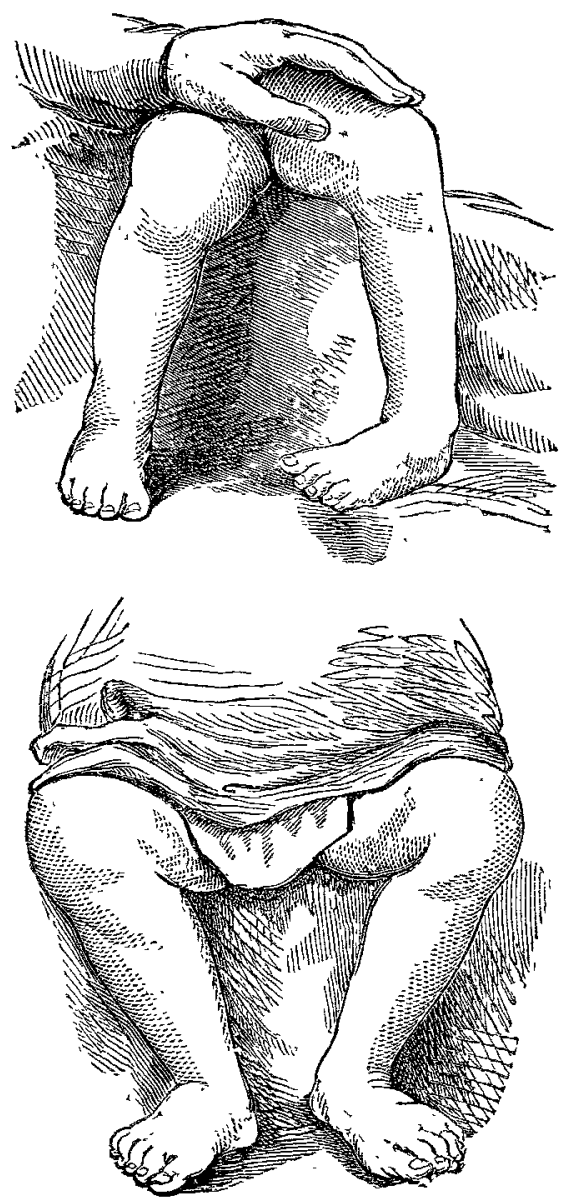

has been written on the subject of imperfect treatment and relapse in such cases by Dr. Little, Mr. Tamplin, Mr. Brodhurst, and more lately by $\mathrm{Mr}$. Wm. Adams in his able treatise. But surgeons seem slow to believe that in talipes varus it is absolutely necessary to carry on active treatment until all that is possible has been done towards restoration of form, \&c., and that afterwards mechanical means for retaining the advantage gained must be persevered in until complete voluntary power over the member is obtained by the patient. In the above case the requisite treatment was used in time, and the child has already obtained such voluntary power as to be able in some degree to dispense with retentive apparatus. The use of the varus shoe at night to keep the foot in good position, and a well-made walking-iron from foot to waist, were absolutely necessary, however, to carry on the treatment; and besides this, the regular performance of manipulations and drill to favour the restoration of voluntary power to the long disused muscles. But every case is not so fortunate. Many perfectly and easily curable cases of talipes varus are still "lamed for life" by imperfect or erroneons treatment in early childhood. A few monthis ago $I$ saw a case of this kind. In early infancy it had been operated on and treated by a distinguished London surgeon. After a few years, its condition not being satisfactory, it was taken to one of the most able of our orthopedists. But it was too late; the greatest skill could not avail to make up for previoas mistakes, and although no money nor pains have been spared, the young gentleman will always suffer in consequence of inefricient treatment in early childhood.

Windermere, April, 1567.

Testmonial to a STrRgox.-A splendid jewel has been presented to Dr. Thomas Diver, of Bombay. It bore the following inscription :- "Presented to Worshipful Brother Thomas Diver, Past Master and District Senior Grand Warden, Bombay, by the members of Concord lodge, No. 757, in testimony of their sippreciation of his valuable and efficient services while presiding orer them as Worshipful Master during the years $186 \pm$ and 1865 , as a slight token of their sense of his zeal and indefatigable exertions in establishing the Lodge charity fund, of his munificent benerolence, and as a mark of grateful regard and sincere onal esteem."

\section{A}

OF THE PRACTICE OF

\section{MEDICINE AND SURGERT IN THE}

\section{HOSPITALS OF LONDON.}

Nulla autem est alia pro certo noscendi via, nisi quamplurimas et morborum of dissectionum historias, tum aliorum, tom proprias collects habere, et inter se comparare.-MoBgaGNI De Sed. et Caus. Morb., lib. iv. Procemium.

\section{MIDDLESEX HOSPITAL.}

CASES OF STRANGULATED HERNIA.

(Under the care of Mr. HuLIsE.)

THE two cases subjoined form a good contrast. In both the constriction was tight, the symptoms acute, the hernia large, the sac unopened; but the one was operated on one hour and a half from the beginning of the strangulation, the other not until two days and a half after. In Case 1, the tissues around the sac were healthy, and the wound healed immediately and soundly-an unusual circumstance, for we often find the skin unite, and reopened after a few days from suppuration beneath it. In Case 2, the tissues about the sac were so injured by the immoderate and unintelligent use of the taxis that a diffuse and fatal cellulitis was provoked, and extensive extrarasations of blood were produced in the subperitoneal tissue of the gut and in the mesentery. These very large extravasations seem more common in large, acute herniæe than in smaller hernix. Mr. Hulke remarked that he had a vivid recollection of some very extensive subperitoneal hæmorrhage in a hernia of this kind, where strangulation happened to a patient in one of the medical wards in King's College Hospital, on whom be operated the same morning. The patient had himself, in his anxiety to avoid an operation, made the roughest attempts to get back the bowel. There the hremorrhage principally occurred along the larger veins; while the hæmorrhage into the gut, which is often in such cases very copious, is always (at least in sereral cases which he had carefully examined with reference to this point it was so) a capillary hæmorrhage, not escaping from any coarsely visible breach of surface. The lesson to be derived is to use the taxis rery gently in these large, acute hermin, and to operate early, always avoiding, if possible, opening the sac; not to slit up the sac if the contents will not go up on dividing the external abdominal ring, where the constriction often is, but to feel for impediments in the nature of tight threads of fascia immediately outside the sac.

CASE 1. Large scrotal hernia; strangulation about an hour. and a half; herniotomy; sac not opened; immediate union of wound; recovery. - A lodging-house keeper, aged fifty, was admitted into Clayton ward at midnight, Oct. 26th, 1866, with a strangulated hernia. The swelling was very large, distending the scrotum greatly, burying the penis, and hiding the testis on the same side. The scrotal part of the hernia was exceed. ingly tender and painful, and it was marked off from the inguinal portion by a deep groove, corresponding to the external abdominal ring. Above this latter there was an impulse when he coughed, but none below it; so that the seat of strangu. lation evidently lay here. The patient had an anxious ex. pression, and was very faint and restless. He had been ruptured since childhood (and this, with the concealment of the testis, made it probable that the hernia was of the con. genital variety), and wore a truss for several years in early life ; but he had left it off until latterly, when he resumed it in consequence of the more frequent descent of the rupture. He had always himself succeeded in reducing the rupture till this time. The descent happened about half an hour before he was brought to the hospital, and was shortly followed by a stool. Gentle pressure failing, he made very forcible attempts to get back the swelling, and these immediately occasioned severe pain. On admission, the house-surgeon put him in a hot bath, and tried the taxis unavailingly.

The manifestly tight constriction at the external abdominal ring, and the great bulk of the hernia, made reduction by taxis most improbable; while the great tenderness, and the already 